\section{Fórum. Centenário de Josué de Castro: lições do passado, reflexões para o futuro. Posfácio}

\author{
Forum. Centennial of the birth of Josué \\ de Castro: lessons from the past, reflections for \\ the future. Postscript
}

\footnotetext{
1 Centro de Estudos e Pesquisas Josué de Castro, Recife, Brasil.

2 Universidade Federal do Rio de Janeiro, Rio de Janeiro, Brasil.

Correspondência

T. Sales

Centro de Estudos e Pesquisas

Josué de Castro.

Rua São Gonçalo 118

Recife, $P E$

50070-600, Brasil.

tsales@uol.com.br
}

Num depoimento memorialista e autobiográfico, prestado ainda na amarga experiência do exílio, Josué de Castro se definia, existencialmente, como um "homem profundamente interessado pelo espetáculo do mundo" com suas dores, suas mazelas, suas dúvidas, suas conquistas, suas potencialidades e suas esperanças. Mas, usando a metáfora da dramaturgia, não era o interesse passivo da platéia face às luzes chaplinianas da ribalta. Autor e ator do próprio script, Josué de Castro se fez corpo, sangue, alma e ícone, como pensador e homem de ação individual e pública face ao mais antigo, mais complexo e mais desafiador dos problemas humanos - o drama universal da fome coletiva, suas origens e suas conseqüências.

É essa figura excepcional, considerada pelo escritor francês André Malraux como uma das quatro celebridades mundiais que demarcaram as idéias e os movimentos sociais do século XX, que se resgata neste Fórum comemorativo de seu centenário de nascimento. Com uma obra que passa pela história, política, geografia, sociologia, epidemiologia, economia, ecologia e outros campos conexos, fica difícil, para biógrafos e analistas, compreender Josué de Castro em toda sua extensão e profundidade. Seria essa uma das impressões mais fortes que resultam da leitura dos artigos que compõem o Fórum.

Malaquias Batista Filho tem repetido, nas várias intervenções que vem participando no programa de comemorações alusivas ao nascimento
Tereza Sales 1

Luciano Vidal-Batista 2

de Josué de Castro, sua dívida de gratidão com o autor de Geografia da Fome e Geopolítica da Fome, como fonte permanente de motivação, idéias, visões do mundo e referência profissional. E é nessa condição que destaca duas grandes características de Josué de Castro, como pensador e homem de ação: a doutrina e a prática coerentemente juntas, de tal forma que, em sua vida, a força da palavra se materializava e se validava na força do exemplo. São características de personalidade que lastreiam sua atividade como cientista, pensador e homem público, cujo legado se projeta para a agenda dos problemas humanos do século XXI. O que hoje se tem no Brasil, como o instituto do salário mínimo, a regulamentação do programa de alimentação do escolar, a consolidação institucional da Segurança Alimentar, a novíssima Lei Orgânica de Segurança Alimentar, têm seus passos iniciais demarcados pela contribuição de Josué de Castro. Mais ainda, muito do que se faz na Organização das Nações Unidas, por meio da FAO (Organização das Nações Unidas para Agricultura e Alimentação), da OMS (Organização Mundial da Saúde), do UNICEF (Fundo das Nações Unidas para a Infância) ou de várias organizações não-governamentais que têm atuado em projetos bi ou multilaterais de desenvolvimento econômico e social, têm, na sua fundamentação, proposições apoiadas em suas idéias e experiências pioneiras.

A obra de Josué de Castro é retomada em outra perspectiva no artigo que se seguiu, Geografia 
da Fome: Clínica de Paisagens ou Epidemiologia Crítica? Pensador da saúde coletiva permanentemente mobilizado pelas questões epistemológicas que envolvem o conceito, o uso e as perspectivas da epidemiologia (como Nájera e Berlinger na Europa, Breilh na América Latina, Sergio Arouca e Naomar Almeida Filho no Brasil), Djalma Agripino de Melo Filho apresenta uma análise instigante para a compreensão atual da obra de Josué de Castro. Com razão, se surpreende pelo fato de que, em plena efervescência da teoria da complexidade e do discurso da transdisciplinaridade, o mais transdisciplinar, mais inovador e mais universal dos estudiosos dos problemas de saúde coletiva no Brasil, com base na ótica alimentar/ nutricional, não tenha exercido uma influência mais relevante no ideário e no movimento epidemiológico que se processa em nosso país.

É paradoxal verificar que, mesmo tendo sido objeto de duas dezenas de trabalhos acadêmicos após sua morte, como ensaios biográficos, interpretações de sua obra em variados domínios da nutrição e seus desdobramentos na geografia, na sociologia, na economia, na antropologia e até na estética, Josué de Castro só raramente seja citado nos textos de epidemiologia. Na realidade, apenas quatro vezes, na abordagem do espaço em estudos epidemiológicos.

Djalma Agripino de Melo Filho debate a questão numa perspectiva dicotômica, ao situar, interrogativamente, a contribuição de Josué de Castro como clínica de paisagem ou epidemiologia crítica. É claro que a interrogação não resolve o dilema, até porque se multiplica em outras perguntas, incluindo a mais radical de todas: teria sido Geografia da Fome um estudo epidemiológico, seja no conceito clássico ou na ótica mais atual dos autores que se aplicam à abordagem do processo saúde/doença em nível populacional?

O próprio Josué de Castro responde a essa questão, explicitando o enfoque epidemiológico da Geografia da Fome e a vertente teórica adotada em sua obra. Por seu lado, Melo Filho referencia os vários momentos, várias idéias e vários tratamentos em que Geografia da Fome se apóia (ou se afasta) das diversas correntes e relevos que demarcaram a evolução da epidemiologia nos últimos 60 anos. Isso incluiu a visibilidade mais atual: holística, transdisciplinar, crítica e compromissada com a nova ética, concepção e diretrizes do desenvolvimento humano.

Na verdade, a obra Josué de Castro atende aos vários papéis da epidemiologia, mas ultrapassa os modelos e modismos de cada época. E nessa ultrapassagem deixa de ser classificada conforme prescrevem os próprios modelos e suas matrizes paradigmáticas. Seria a mesma dificuldade de enquadrar, num outro campo, Leonardo da
Vinci (escultor, pintor, anatomista, inventor de engenhos para a guerra e para a paz) ou Einstein, ou René Dubeaux: não cabem nos figurinos.

Ricardo Abramovay contribui para o Fórum trazendo o próprio Josué de Castro para os dias atuais. O autor de Geografia da Fome passa a dialogar, pelas mãos e arte de Abramovay, com autores e temas que estão hoje no foco mais aceso das discussões acadêmicas e da agenda da geopolítica. Enfatizando a abordagem interdisciplinar de Josué de Castro, duas dimensões são ressaltadas: a biodiversidade ("embora a noção não esteja claramente formulada, a Geografia da Fome encontra-se entre os mais belos elogios já produzidos no Brasil a respeito de sua biodiversidade"); e a reunificação daquilo que a constituição das ciências contemporâneas separou, qual seja, a natureza e a sociedade. $\mathrm{Ou}$, em outros termos, o meio ambiente e o desenvolvimento. Nessa perspectiva interdisciplinar, Abramovay coloca Josué de Castro em diálogo com uma instigante e atual bibliografia de autores contemporâneos identificados com a economia ecológica e que procuram ligar sistemas sociais e sistemas ecológicos. Para o autor do artigo, é nessa ligação que está a chave para compreender e enfrentar os desafios alimentares do século XXI.

Para Abramovay, o mais importante na obra de Josué de Castro não seria o tema sobre o qual ele se debruçou, e sim o método que empregou para estudá-lo (ao qual ele chamou de método geográfico), tornando-se um verdadeiro precursor da abordagem sócio-ambiental dos problemas de nosso tempo. Também aqui, e não apenas no diálogo com autores atuais, convida Josué de Castro a tomar assento nos dias de hoje; no caso, na sua atuação de homem público que não apenas estudou, mas propôs soluções. Pois, segundo Abramovay, é exatamente esse método que permite não apenas compreender, mas, sobretudo, delinear as políticas necessárias para enfrentar o desafio do aumento da população mundial dos 6,5 bilhões de habitantes atuais para um horizonte de estabilização de 9,2 bilhões em 2050. E mais: temas tão atuais e candentes que estão a ocupar as páginas da imprensa quase todos os dias, tais como a explosão mundial dos preços dos alimentos, não apenas se explicam pelo aumento da renda dos países emergentes ou a opção norte-americana de dedicar grande parte de sua produção de milho como matéria prima para a obtenção do etanol. Essa elevação dos preços dos alimentos deve ser também interpretada pela ótica da oferta, tal como propôs Josué de Castro, a partir das condições ecológicas em que esta oferta se realiza.

Recebido em 18/Jul/2008

Aprovado em 04/Set/2008 